\title{
Genotype and Allele Frequencies of -2841 A $>$ T Polymorphism in Glucose Transporter 1 gene in Turkish Population
}

\author{
Zeliha KAYAALTI, Fezile ÖZDEMİR, Dilek KAYA- AKYÜZLÜ, Tülin SÖYLEMEZOĞLU
}

\begin{abstract}
Glucose transporter 1 (GLUT1) is located in basolateral side of cells and mediates the unidirectional transport of glucose as non-insulin dependent glucose transporter protein. It is responsible for transportation of glucose especially to cancer cells and also transports arsenic compounds that is related with diabetes mellitus. The present study aimed to detect the allele and genotype frequencies of GLUT1 -2841A $>$ T single nucleotide polymorphism (SNP) in Turkish population. Blood samples were collected from unrelated 100 male and 110 female. Polymerase Chain Reaction (PCR)-Restriction Fragment Length Polymorphism (RFLP) technique was used
\end{abstract}

to analyze the blood samples. The distribution of $-2841 \mathrm{~A}>\mathrm{T}$ SNP was $55.2 \%, 38.1 \%$ and $6.7 \%$ for AA, AT and TT genotype, respectively. The frequency of the A allele was found as $74.3 \%$ and those of the $\mathrm{T}$ allele as $25.7 \%$. The statistical evaluation represented that the allele frequencies was accordant with Hardy- Weinberg equilibrium $\left(\chi^{2}=0.002, \mathrm{p}=0.97\right)$. This was the first study examining the frequencies of GLUT1 $-2841 \mathrm{~A}>\mathrm{T}$ polymorphism in Turkish population. In our opinion, these results can be used in epidemiological studies both in Turkey and other countries.

Keywords: Glucose transporter 1; Turkish population; polymorphism; HpyCH4V.
Zeliha KAYAALTI, Fezile ÖZDEMİR, Dilek KAYA- AKYÜZLÜ, Tülin SÖYLEMEZOĞLU

Ankara University Institute of Forensic Sciences,

Ankara University, Institute of Forensic Sciences, Dikimevi, 06590, Ankara, Turkey

Corresponding Author: Zeliha KAYAALTI

Ankara University Institute of Forensic Sciences

E-mail:kayaalti@ankara.edu.tr

Address: Institute of Forensic Sciences, Ankara University, Dikimevi, 06590, Ankara, Turkey

Tel: +903123192734

Fax: +903123192077

Submitted/Gönderilme: 25.02.2016

Accepted/Kabul: 31.03.2016
Revised/Düzeltme: 25.03.2016

\section{INTRODUCTION}

Glucose transporter 1 (GLUT1), encoded by SLC2A gene, contains 12 alpha- helical transmembrane domain and is located in basolateral side of cells. Depending on the glucose concentration, GLUT1 mediates the unidirectional transport of glucose from exo- to endofacial site in the cell (1). GLUT1 was firstly isolated from erythrocytes and the first isolated sugar transporter (1). The level of the GLUT1 is different in all cell types due to the glucose metabolism $(1,2)$. GLUT1 mostly is expressed in the cardiovascular system, brain (in astrocytes), erythrocytes and less extent in the liver, the muscle, the kidney (tubular and glomerular areas) and the adipose tissue $(1,3)$.

The expression of GLUT1 is induced in the carcinogenesis and in the pathogenesis of diabetic nephropathy. Cancer cells need a greater energy for abnormal proliferation that causes metastasis. This energy is supplied by anaerobic glycolysis and 2 molecules of ATP are obtained from a molecule of glucose. Thus, glucose uptake is extremely increased in 
hypoxic cells. A hypoxia responsive transcription factor (hypoxia-inducible factor 1 a (HIF-1 a) also serves as a regulator for proliferation and survival of cancer cells in this hypoxic condition. The HIF-1 a binds to the hypoxia responsive recognition element (HRE) and enhances the transcription of target genes including GLUT1 (2, 4-7). In the pathogenesis of diabetic nephropathy in patients with Diabetes Mellitus, GLUT1 is one of the rate-limiting factors (8-10). A to $\mathrm{T}$ substitution is at -2841 in the promoter region of GLUT1 gene so it can alter the over- or lessexpression of protein synthesis (8). Increase of blood glucose level causes hyperglycemia, which induces some changes in kidney such as increase of glomerular mesangial synthesis, renal hypertrophy, glomerulosclerosis and accumulation of extracellular matrix proteins. Furthermore, GLUT1 transports arsenic compounds right along with glucose in erythrocytes, blood-brain barrier, epithelial cells, tubular and glomerular part of the kidney, and, thus, it may be an important protein in the risk of diabetes in case of chronic arsenic exposure $(11,12)$.

It is an indisputable fact that cancer is a disease of our age. According to the IARC GLOBOCAN 2012 data, 14.1 million individuals have cancer and 8.2 million people die due to the cancer every year in the world (13). When we look at the Turkey, approximately 103.070 men and 71.233 women have cancer in every year (14). In 2014, 4.9 billion deaths occurred because of the diabetes and about 387 million individual had diabetes in the worldwide. Besides, the number of patients with diabetes is approximately 7.2 million and due to the diabetes 59000 people die every year in Turkey (15).

Considering all of these incidences, the occurrence of cancer and diabetes may evaluate as a big threat for human nowadays. GLUT1 has been thought an important role in pathogenesis of cancer and diabetes. Thus, the aim of the study was to determine the genotype and allele frequency of $-2841 A>T$ single nucleotide polymorphism (SNP) in GLUT1 gene (rs710218; GeneID: 6513; Accession Number: NM_006516) in Turkish population and to compare our data with other populations.

\section{MATERIAL AND METHODS}

\section{Subjects}

The specimens were obtained from volunteers who were checked up in hospital. Each subject provided written informed consent and approval (approval no: 06-242-13 in 2013) for the use of human subjects was obtained from the institutional ethics committee. A small survey used to gather demographic information was given to all subjects. The 210 blood samples were collected from Turkish 100 male and 110 female who is between the ages of 18 and 41 years. Whole blood samples were collected into ethylenediaminetetraacetic acid anticoagulant tubes and were kept at $4{ }^{\circ} \mathrm{C}$ until analyze. The anamneses indicate that individuals are unrelated and healthy (no history of disease such as chronic diseases and cancer). The study was in accordance with the principles of the Declaration of Helsinki.

\section{Isolation of DNA and Genotyping of GLUT1 -2841 A $>$ T Polymorphism}

DNA was extracted from whole-blood by Qiagen QIAamp DNA Mini Kit. DNA concentration was determined using the PicoGreen dsDNA quantitation kit (Molecular Probes, Eugene, OR) according to the method recommended by the manufacturer.

For detection of the GLUT1 -2841A>T polymorphism, 337 bp fragment was amplified by Polymerase Chain Reaction (PCR) using the following primers: forward: 5'-GCTGAGAATGGCCTTCCCTCAAT-3' and reverse primer 5'-CTGCCTTACTCAGCCCATGGGTC-3'. The PCR reaction mixture contained 10x PCR buffer, $200 \mu \mathrm{M}$ dNTP, $10 \mu \mathrm{l}$ from each of the primers, $1.25 \mathrm{U}$ of Hot Star Taq DNA polymerase (Qiagen), 200 ng DNA and last volume completed with distilled water to $50 \mu$ l. Amplification was conducted on a Techne Tc 512 PCR System. The PCR cycling conditions consisted of an initial denaturation step at $94^{\circ} \mathrm{C}$ for $10 \mathrm{~min}$; 35 cycles of $94{ }^{\circ} \mathrm{C}$ for $1 \mathrm{~min}, 6{ }^{\circ} \mathrm{C}$ for $1 \mathrm{~min}, 72{ }^{\circ} \mathrm{C}$ for 1 min; and a final extension step at $72{ }^{\circ} \mathrm{C}$ for $5 \mathrm{~min}$. Then, the RFLP method was used for the determination of $-2841 A>T$ polymorphism in GLUT1 gene. For this purpose, $337 \mathrm{bp} \mathrm{PCR}$ products were digested with $H p y C H 4 V$ restriction enzyme (New England Biolabs, Hertfordshire, UK) and incubated at $37{ }^{\circ} \mathrm{C}$ overnight. Digested and undigested products were separated by gel electrophoresis on a $2 \%$ agarose gel and visualized by ethidium bromide so the staining under an ultraviolet illuminator. Then, the Syngene Monitoring System was used for scanning and photographing. The obtained fragments represented the presence of A allele (208+129 bp) and the T allele (337 bp) (Figure 1). Results of RFLP for each variant in 30 randomly selected samples were confirmed by DNA sequencing method using the Big-Dye Terminator Cycle Sequencing Ready Reaction kit on an ABI Prism 3100 Genetic Analyzer. The automated DNA sequencing was employed to confirm the authenticity of the amplified PCR products. 


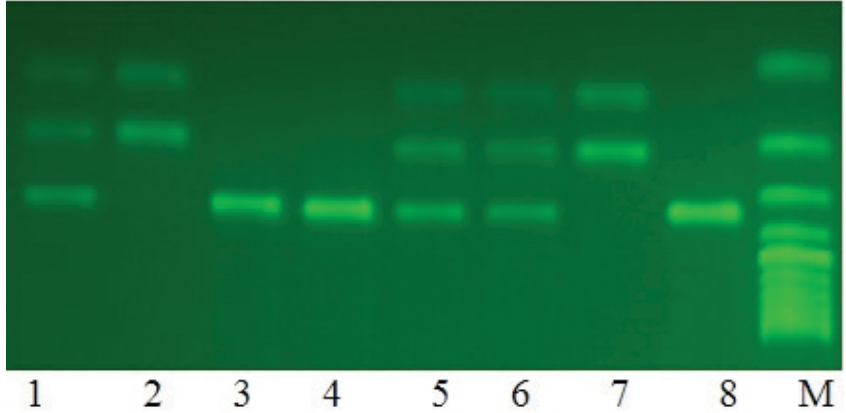

Figure 1. A representative agarose gel image of digested and undigested PCR products with HpyCH4V: M: 100-bp ladder; Lanes 1, 5 and 6: AT (337, 208, 129 bp); Lanes 2 and 7: AA (208, 129 bp); Lanes 3 and 4: TT (337 bp); Lane 8: undigested PCR product (337 bp).

\section{Statistical analysis}

The statistical data was analyzed using SPSS 16 software. The frequencies of GLUT1 alleles and genotypes were obtained by direct count and the $\chi^{2}$ test was used for evaluation of the Hardy-Weinberg equilibrium. Continuous variables are reported as mean \pm standard deviation (S.D.). Categorical variables were compared by the $\chi^{2}$ test. Results were considered to be statistically significant at $\mathrm{p}<0.05$.

\section{RESULTS}

The mean age of study subjects was $29.24 \pm 4.98$ years (range 18-41 years). The genotype frequencies were 55.2\% homozygote typical (AA), 38.1\% heterozygote (AT) and 6.7\% homozygote atypical (TT) (Table 1 and 2). The $A$ and $T$ allele frequencies were found as $74.3 \%$ and $25.7 \%$, respectively. The genotype frequencies in all subjects were consistent with Hardy-Weinberg equilibrium $(\chi 2=0.002 ; \mathrm{p}=0.97)$.

GLUT1 -2841A>T single nucleotide polymorphism was also statistically evaluated for significance with gender and age. No significant differences were found between genders and ages $(\mathrm{p}>0.05)$

Table 1. Distribution of Glut1 -2841A > T polymorphism in healthy Turkish population.

\begin{tabular}{|c|c|c|c|c|c|c|c|c|c|c|c|c|}
\hline \multirow{3}{*}{ Sample } & \multicolumn{7}{|c|}{ Genotype frequency } & \multicolumn{5}{|c|}{ Allele frequency } \\
\hline & \multirow{2}{*}{$\begin{array}{c}\text { n } \\
(210)\end{array}$} & \multicolumn{2}{|c|}{ AA } & \multicolumn{2}{|c|}{ AT } & \multicolumn{2}{|c|}{ TT } & \multirow{2}{*}{$\begin{array}{c}\text { n } \\
(420)\end{array}$} & \multicolumn{2}{|c|}{ A } & \multicolumn{2}{|c|}{$\mathbf{T}$} \\
\hline & & $\mathbf{n}$ & $\%$ & $\mathbf{n}$ & $\%$ & & $\%$ & & $\mathbf{n}$ & $\%$ & $\mathbf{n}$ & $\%$ \\
\hline Female & 110 & 57 & 51.8 & 44 & 40 & 9 & 8.2 & 220 & 158 & 71.8 & 62 & 28.2 \\
\hline Male & 100 & 59 & 59.0 & 36 & 36.0 & 5 & 5.0 & 200 & 154 & 77.0 & 46 & 23.0 \\
\hline $\mathbf{p}$ & & & & & 0.471 & & & & & & & \\
\hline
\end{tabular}

Table 2. Comparison of the genotype frequency distributions of GLUT1 -2841A $>$ T polymorphism in Turkish population and previously published data in other populations.

\begin{tabular}{|c|c|c|c|c|c|c|c|}
\hline \multirow{3}{*}{ Population } & \multicolumn{7}{|c|}{ Genotype frequency } \\
\hline & \multirow{2}{*}{$\mathbf{n}$} & \multicolumn{2}{|c|}{ AA } & \multicolumn{2}{|c|}{ AT } & \multicolumn{2}{|c|}{ TT } \\
\hline & & & $\%$ & $\mathbf{n}$ & $\%$ & $\mathbf{n}$ & $\%$ \\
\hline $\begin{array}{c}\text { Turkish (present } \\
\text { study) }\end{array}$ & 210 & 116 & 55.2 & 80 & 38.1 & 14 & 6.7 \\
\hline German & 127 & 64 & 50.4 & 52 & 40.9 & 11 & 8.7 \\
\hline British & 99 & 32 & 32.3 & 65 & 65.7 & 2 & 2.0 \\
\hline
\end{tabular}




\section{DISCUSSION}

Single nucleotide polymorphisms are one of the most important factors that affect the occurrence of a disease, the sensitivity to xenobiotics and/or the side effects of drugs between individuals. The development of personalized drug therapy, the drug sensitivity and biotransformation of drugs is determined by starting with identify SNP (16). Most SNPs occur in the non-coding region and can be alter genes, whereas SNPs occurring in the coding regions could alter the protein. A single nucleotide base mutation which occurs in the promoter region can affect transcription and post-transcription and finally translation although; they do not appear in proteins (17). In present study, $-2841 A>T$ polymorphism in GLUT1 gene was studied. Because, A to $\mathrm{T}$ substitution is at -2841 in the promoter region of GLUT1 gene so it can alter the over- or less-expression of protein synthesis (8) and there isn't any study in literature about $-2841 A>T$ polymorphism in GLUT1 gene in Turkish population. Determination of these polymorphisms is also significant information with regard to relation between societies. Turkey is located in the transition region of Europe and Asia continents. Thus, there is heterogeneity and genetic admixture in Turkey and the investigation of the allele frequencies and genotype distributions of some variants is important in a pharmacogenetic interest in this population. In the previous studies the GLUT1 promoter polymorphism $-2841 A>T$ and its effect to the hepatic carcinoma cells were studied in a German population (5). Also, the association of $-2841 A>T$ polymorphism in GLUT1 promoter region with diabetic nephropathy in patients with Type 1 diabetes mellitus was examined in a British population (8). However, there has been no study related to the $-2841 A>T$ polymorphism in GLUT1 in Turkish population. Thus, to the best of our knowledge, this is the first research aiming to determine the genotype and allele frequencies of GLUT1 $-2841 A>T$ polymorphism in Turkish population. Table 2 showed the

Türk popülasyonunda Glukoz Trasnporter 1 geninde $-2841 \mathrm{~A}>\mathrm{T}$ polimorfizminin allel ve genotip frekansının belirlenmesi

öz

Glukoz transporteri (GLUT1) hücrenin bazolateralinde yer almaktadır ve insulinden bağımsız olarak glukozun tek yönlü taşınımını sağlar. Özellikle kanser hücrelerine glukoz taşımasından sorumlu olan GLUT1 ayrıca, diyabetle ilişkili olarak arsenik bileşiklerini de taşınmaktadır. Söz konusu çalışma, Türk popülasyonundaki GLUT1 (A2841T) tek nükleotit polimorfizminin allel ve genotip frekansını belirlemeyi amaçlamaktadır. Birbirinden bağımsız 100 erkek genotype and allele frequencies in Turkish, healthy group of German and British populations. According to this table, distribution of $-2841 A>T$ polymorphism in Turkish seemed to be almost similar with German population, but different from British population.

According to the previous studies, the expression of GLUT1 induces and glucose uptake increases in cancer cells in the presence of GLUT1 -2841A>T allele. Thus, required energy for anaerobic respiration obtains and proliferation increases. Furthermore, in hypoxic condition, due to the anaerobic respiration the HIF-1 a binding affinity induces expression of GLUT1 (2, 5 and 9). Also, there have been some studies investigating the relationship of GLUT1 SNPs with the development of diabetes. Based on these studies, the A allele in -2841 in GLUT1 gene has a protective role against diabetes (8). When compare with other genotypes, the glucose uptake is less in the presence of $\mathrm{A}$ allele. Thus, the pathogenesis of hyperglycemia and occurrence of renal disease is slightly less. Although previous studies indicated that GLUT1 transports arsenic as well as glucose in erythrocytes, in blood-brain barrier and in epithelial cells $(12,18)$, the association between this GLUT1 and the concentration or transport of arsenic in cells has not been studied yet.

Our study results may provide a perspective for future studies concerning the role of $-2841 A>T$ polymorphism in GLUT1 gene as a susceptibility factor for cancer and diabetes epidemiology. The present results may use as a control group for such studies and may assist to develop an individualized drug for patients with cancer and diabetes in the future. Also, further studies need to examine possible correlation between the effects of this polymorphism on the accumulation of heavy metals in the biological samples.

\section{CONFLICT OF INTEREST}

The authors have nothing to declare.

ve 110 kadından kan örnekleri toplanmıştır. Polimeraz Zincir Reaksiyonu- Restriksiyon Fragment Uzunluk Polimorfizmi tekniği ile kan önrekleri analiz edilmiștir. $-2841 \mathrm{~A}>\mathrm{T}$ polimorfizminin AA, AT ve TT genotiplerine göre dağılımı sirasıyla, \%55.2, \%38.1 ve \%6.7'dir. A allelinin sıklığ $\% 74.3$, $\mathrm{T}$ allelinin ise \%25.7'dir. İstatiksel analizler sonucunda elde edilen verilerin, Hardy- Wienberg eşitliği ile uyumlu olduğu saptanmıştır. Söz konusu çalışma GLUT1 -2841A>T polimorfizmini Türk popülasyonunda araştıran ilk çalışmadır. Sonuç olarak, elde edilen sonuçlar Türkiye ve diğer ülkelerdeki epidemiyolojik çalışmalarda kullanılabilecektir.

Anahtar kelimeler: Glukoz transporter 1, Türk popülasyonu, polimorfizm, HpyCH4 


\section{REFERENCES}

1. Robichaud T, Appleyard AN, Herbert RB, Henderson PJF, Carruthers A. Determinants of Ligand Binding Affinity and Cooperativity at the Glut1 Endofacial Site. Biochem 2011; 50: 3137-48.

2. Amann T, Hellerbrand C. GLUT1 as a Therapeutic target in hepatocellular carcinoma. Expert Opin Ther Targets. 2009; 13: 1411-27.

3. Wood S, Trayhurn P. Glucose transporters (GLUT and SGLT): expanded families of sugar transport proteins. Br J Nutr 2003; 89: 3-9.

4. Ganapathy V, Thangaraju M, Prasad PD.Nutrient transporters in cancer: Relevance to Warburg hypothesis and beyond. Pharmacol Ther 2009; 121: 29-40.

5. Ammann T, Kurovski G, Bosserhoff AK, Hellerbrand C. Analysis of a promoter polymorphism of the GLUT1 gene in patients with hepatocellular carcinoma. Mol Membr Biol 2011; 28: 182-186.

6. Semenza GL, Wang GL. A nuclear factor induced by hypoxia via de novo protein synthesis binds to the human erythropoietin gne enhancer at a site required for transcriptional activation. Mol Cell Bio 1992; 12: 5447-54.

7. Semenza GL. Involvement of hypoxia- inducible factor 1 in human cancer. Intern Med 2002; 41: 79-83.

8. Hodgkinson AD, Page T, Millward BA, Demaine AG. A novel polymorphism in the 5' flanking region of the glucose transporter (GLUT1) gene is strongly associated with diabetic nephropathy in patients with Type 1 diabetes mellitus. J Diabetes Complicat 2005; 19: 65-69.

9. Cui W, Du B, Zhou W, Jia Y, Sun G, Sun J, Zhang D, Yuan H, Xu F, Lu X, Luo P, Miao L. Relationship between five Glut1 gene single nucleotide polymorphisms and diabetic nephropathy: a systematic review and meta-analysis. Mol Biol Rep. 2012; 39 : 8551-58.
10. Mogyorosi A, Ziyadeh FN. GLUT1 and TGF- $\beta$ : the link between hyperglycaemia and diabetic nephropathy. Nephrol Dial Transplant. 1999; 14: 2827-29.

11. Islam R, Khan I, Hassan N, McEvoy M, D’Este C, Attia J, Peel R, Sultana M, Akter S, Milton A H. Association between type 2 diabetes and chronic arsenic exposure in drinking water: A cross sectional study in Bangladesh. Environ Health 2012; 11:38.

12. Liu Z, Sanchez M A, Jiang X, Boles E, Landfear S M, Rosen B P. Mammalian glucose Permease Glut1 facilitates transport of arsenic trioxide and methylarsonous acid. Biochem Biophys Res Commun 2006; 351:424-30.

13. International Agency for Research on Cancer. GLOBOCAN 2012: Estimated Cancer Incidence, Mortality and Prevalence Worldwide in 2012. http://globocan.iarc.fr/Pages/fact_sheets_ cancer.aspx. Accessed 18 May 2015.

14. Turkey Public Health Association. Cancer Incidence. 2013. http://kanser.gov.tr/Dosya/2016_Haberler/KANSER_ iNSiDANSLARi_2013_kisa_rapor.pdf. Accessed 19 Feb 2016.

15. International Diabetes Federation. IDF Diabetes Atlas Sixth edition. 2014. http://www.idf.org/sites/default/files/Atlasposter-2014_EN.pdf. Accessed 18 May 2015.

16. Chaudhary R, Singh B, Kumar M, Gakhar SK, Saini AK, Parmar VS, Chhillar AK. Role of single nucleotide polymorphism in pharmacogenomics and their association with human diseases. Drug Metab Rev 2015; Early online 1-10.

17. Kayaalti Z, Odabaşi M, Söylemezoğlu T. Genotype and allele frequencies of divalent metal transporter 1 polymorphism in Turkish population. Mol Bio Rep 2011; 38: 2679-84.

18. Rosen B P and Liu Z. Transport pathways for arsenic and selenium: A minireview. Environ Int 2009; 35: 512-5. 